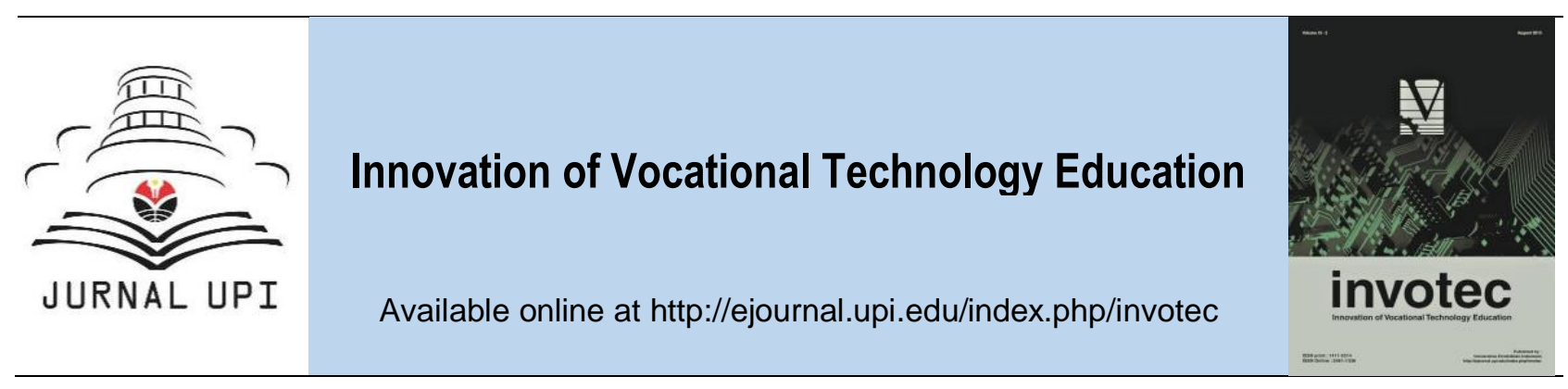

\title{
The Influence of Proportion of Yellow Pumpkin (Cucurbita Moschata) Flour and Red Rice (Oryza Glaberrima) Flour towards Organoleptic Properties of Food Bar
}

\author{
M. G. Miranti \& J. B. Helga \\ State University of Surabaya, Indonesia
}

\section{ARTICLE INFO}

\section{Article history:}

Received 5 January 2018

Received in revised form 31 January

2018

Accepted 14 February 2018

Available online 28 February 2018

Keywords:

food bar, red rice flour, yellow pumpkin flour, organoleptic properties

Corresponding author:

maurenmiranti@unesa.ac.id

\section{A B S T R A C T}

Food bar is food with a bar-like shape which contains adequate energy and nutrition. This study aims to determine the right proportion between red rice flour and yellow pumpkin flour as well as to analyze the influence of said proportion towards organoleptic properties of the food bar. The proportions between red rice flour and yellow pumpkin flour used in this study are $40 \%$ and $60 \%, 50 \%$ and $50 \%$, and $60 \%$ and $40 \%$. With those varying proportions, the food bars are organoleptically tested based on their color, smell, taste, blendability and favorite level. The study shows that the proportion of red rice flour and yellow pumpkin flour has an impact on the organoleptic properties of the food bar such as the taste, blendability, and favorite level. However, the proportion has no effect on the color and smell of the food bar. The best food bar product contains the proportion of $50 \%$ red rice flour and $50 \%$ yellow pumpkin flour. Nutrions found per $100 \mathrm{~g}$ are $144.2 \mathrm{kcal}$ energy, $26 \mathrm{~g}$ carbohydrate, $15.38 \mathrm{mg}$ calcium, $4.56 \mathrm{~g}$ fat, $2.18 \mathrm{~g}$ protein, 34.32mg phosphor, 83.04 RE vitamin $A, 0.04 \mathrm{mg}$ vitamin B1, 13.26mg vitamin C.

\section{Introduction}

Food bar is a solid food product which has a bar-like shape. It is a mixture various dry ingredients such as cereal, nuts, dried fruits which are combined into a binder. The binder can be made from syrup, nougat, caramel, chocolate, etc (Ekafitri and Faradilla, 2011). According to Kusumastuty, et. al (2015) food bar is originally a food distributed in case of natural disaster; this ready to eat food has enough energy and nutrition which can also be improved to supply calorie, protein, fat and other nutritional needs to serve as a functional food. All in all, food bar is a solid barshaped ready-to-eat food containing adequate energy and nutrition.

In the process of making this food bar, a combination of red rice flour and yellow pumpkin flour is used. Nuryani (2013) states that fiber found in the husk of rice type such as red rice is very effective in preventing gastrointestinal diseases as well as diseases related to cholesterol. The anthocyanin pigment in red rice which gives red rice the color it has acts as an antioxidant to prevent various diseases such as coronary heart, cancer, diabetes, and hypertension.

Fiber found in red rice is at $5.4 \%$, but only $2.7 \%$ in wheat flour. The capacity of antioxidant red rice has is $6.08 \mathrm{mg}$ AEAC/100g (bk) (Goufo and Trindade, 2014). One of the most common product of processed red rice is flour. The aim of producing flour from local food is to make the product last 
longer, easier to store, to be more practically verified, to serve as additional way of processing red rice, and to reduce the consumption of wheat flour (Silfia, 2012; Suismono and Hidayah, 2011).

Yellow pumpkin has substantial amount of fiber, vitamin and carbohydrate. In Addition, there are also 34 calories, 0.8 fat, $45 \mathrm{mg}$ calcium and 0.8 mineral within the pumpkin. It is why this fruit is very good both for children and the elderly since it gives so much benefits to the human body. In children's case, it is very useful to increase appetite and for dealing with intestinal worms (Pendong, et. al, 2017). Its flour has its own specific attribute and smell. Generally, yellow pumpkin flour can readily go side by side with wheat flour and rice flour to be used in various menus. The quality of yellow pumpkin flour depends on its substance which affects the functional attribute of the batter, the finished product of the flour as well as its water suspension. Yellow pumpkin is a good ingredient for a flour as it has a good gelatinization which results in consistent and spongy batter with great viscosity and elasticity. High amount of carbohydrate can also be found in yellow pumpkin flour. This substance plays a major role in making dough. The starch granules would remain attached to protein while making the dough. This attachment then creates a continuity of the structure of the dough (Imanningsih, 2012).

As a result, red rice and yellow pumpkin are used in making food bar in order to suffice the energy and nutrition needs of human being. Red rice and yellow pumpkin are also relatively easy to find and beneficial for diversification of food. These two ingredients are to be combined with other kinds of ingredients (butter, milk, sugar, beans, and dried fruits) to produce food bar for consumers. The food bar will then be organoleptically tested in terms of color, smell, taste, blendability and favorite level in order to achieve the best kind of food bar.

\section{Method}

The type of this research is experiment. Several ratios will be applied into the combination (Table 1) between red rice flour and yellow pumpkin flour, namely 40\%:60\%, 50\%:50\% and 60\%:40\% respectively.

Table 1. Experiment Design

\begin{tabular}{lccc}
\hline \multicolumn{1}{c}{ Ingredients } & S1 & S2 & S3 \\
\hline Red Rice Flour & $40 \%$ & $50 \%$ & $60 \%$ \\
Yellow Pumpkin Flour & $60 \%$ & $50 \%$ & $40 \%$ \\
\hline
\end{tabular}

The technique of data collection is observation. The observation is conducted by testing the organoleptic properties of the three different ratios in term of color, smell, taste, blendability and acceptance. Data is gathered from 35 panelists and the analysis is based on one-way ANOVA test and Duncan's multiple range test (DMRT). The best product is then tested to analyze the nutrition within the food bar by using DKBM (list of ingrdients list composition).

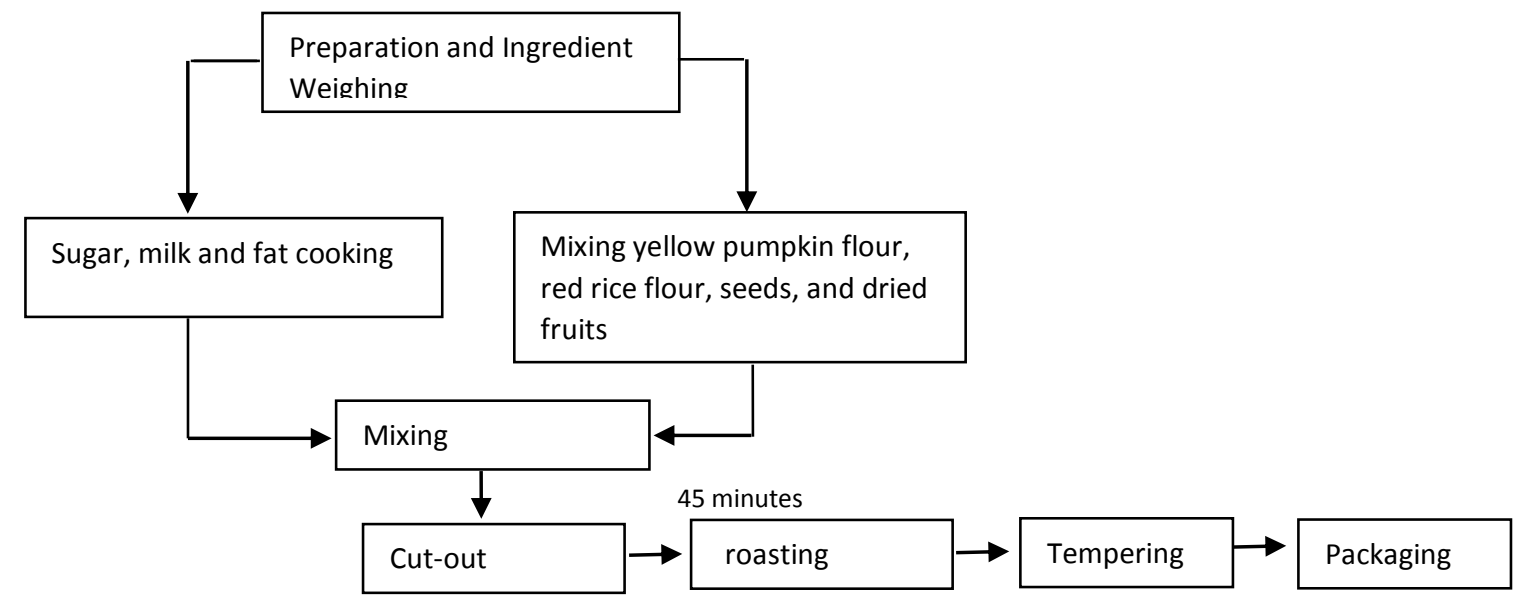

Figure 1. Process of making Food Bar 
The ingredients used in the making of food bar are red rice flour and yellow pumpkin flour. On one hand, the red rice flour is made by soaking red rice in water for 12 hours, which is then ground and dried. The total red rice flour used for the $40 \%, 50 \%$ and $60 \%$ ratios are $50 \mathrm{~g}$. The yellow pumpkin flour used, on the other hand, is made by boiling yellow pumpkin for 5 minutes, which is then sliced, dried, and ground. The same amount of yellow pumpkin flour is used for the $40 \%, 50 \%$, and $60 \%$ from total flour which is $50 \mathrm{~g}$. Other ingredients used are sugar, hollmann butter, sweetened condensed milk, dried yellow pumpkin seed, dried sunflower seed, dried cranberry sweets. The process of making food bar can be seen Figure 1.

\section{Result and Discussion}

Based on the result of organoleptic the highest average is in the treatment with the proportion of $60 \%$ red rice flour and $40 \%$ yellow pumpkin flour which is 3.77 with light brown food bar color. The results of one-way ANOVA test shows that the proportion of red rice flour and yellow pumpkin flour does not affect the color of the food bar. It does not affect the color of the food bar since the finished product turns out to have the same color that is light brown color. The color is created from cooking sugar. Sugar which is cooked experiences caramelization process that changes its color to brown. Table 2 is the result of one-way ANOVA test on food bar color:

Tabel 2. One-way ANOVA test on color

\begin{tabular}{lcrcrr}
\hline & Sum of Squares & df & Mean Square & $\mathrm{F}$ & Sig. \\
\hline Between Groups & 1.267 & 2 & .633 & .748 & .476 \\
Within Groups & 73.633 & 87 & .846 & & \\
Total & 74.900 & 89 & & & \\
\hline
\end{tabular}

The highest average is in the treatment with the proportion of $40 \%$ red rice flour and $60 \%$ yellow pumpkin flour which is 2.47. The result of one-way ANOVA test (Table 3) shows that the proportion of red rice flour and pumpkin flour does not affect the food bar smell. The proportion of red rice flour and yellow pumpkin flour does not affect the smell of the food bar as yellow pumpkin flour has specific properties with a distinctive aroma (Hendrasty, 2003), so the resulting product has a distinctive aroma of red rice flour and yellow pumpkin flour.

Table 3. One-way ANOVA test result on smell

\begin{tabular}{lcrccc}
\hline & Sum of Squares & df & Mean Square & F & Sig. \\
\hline Between Groups & .800 & 2 & .400 & .439 & .646 \\
Within Groups & 79.200 & 87 & .910 & & \\
Total & 80.000 & 89 & & & \\
\hline
\end{tabular}

The highest average is in the treatment with the proportion of $60 \%$ red rice flour and $40 \%$ yellow pumpkin flour which is 2.43 with sweet enough taste. The taste of red rice flour and yellow pumpkin flour can still be felt. The result of one-way ANOVA test (Table 4) shows that the proportion of red rice flour and yellow pumpkin flour influences the taste of the food bar. Thus, Duncan's multiple range test (DMRT) is done which can be seen below.

Table 4. One-way ANOVA test on taste

\begin{tabular}{lcrccc}
\hline & Sum of Squares & df & Mean Square & F & Sig. \\
\hline Between Groups & 6.956 & 2 & 3.478 & 4.815 & .010 \\
Within Groups & 62.833 & 87 & .722 & & \\
Total & 69.789 & 89 & & & \\
\hline
\end{tabular}

The result of one-way ANOVA test shows that the proportion of red rice flour and yellow pumpkin flour influences the taste of the food bar. Thus, Duncan's multiple range test (DMRT) is done (Table 5). Based on DMRT, a food bar with a proportion of 50:50 and 60:40 both have similar mild sweet taste and the taste of red rice flour and yellow pumpkin flour themselves can still be felt. The proportion of red rice flour and pumpkin flour does affect the taste of the food bar. The more yellow pumpkin flour is used, obviously, the more dominant the yellow pumpkin taste on the food bar. This is because the pumpkin flour has a very distinctive flavor. 
Table 5. DMRT result on food bar taste

\begin{tabular}{lccc}
\hline \multicolumn{1}{c}{ Food Bar } & \multirow{2}{*}{$\mathrm{N}$} & \multicolumn{2}{c}{ Subset for alpha $=0.05$} \\
\cline { 3 - 4 } & & 1 & 2 \\
\hline BM (40\%) LK (60\%) & 30 & 1.800 & \\
BM (50\%) LK (50\%) & 30 & & 2.333 \\
BM (60\%) LK (40\%) & 30 & & 2.433 \\
Sig. & & 1.000 & .650 \\
\hline
\end{tabular}

The highest average is in the treatment with the proportion of $50 \%$ red rice flour and $50 \%$ yellow pumpkin flour which is 3.1 as the structure of the food bar is quite dense. The result using ANOVA test for blendability on Table 6 .

Table 6. One-way ANOVA test on blendability

\begin{tabular}{lcrccc}
\hline & Sum of Squares & df & Mean Square & F & Sig. \\
\hline Between Groups & 12.422 & 2 & 6.211 & 5.838 & .004 \\
Within Groups & 92.567 & 87 & 1.064 & & \\
Total & 104.989 & 89 & & & \\
\hline
\end{tabular}

The result of one-way ANOVA test shows that the proportion of red rice flour and yellow pumpkin flour does influence the blendability of the food bar. Further analysis based on DMRT is done in Table 7.

Table 7. DMRT result on blendability of the food bar

\begin{tabular}{lccc}
\hline \multicolumn{1}{c}{ Food Bar } & $\mathrm{N}$ & \multicolumn{2}{c}{ Subset for alpha $=0.05$} \\
\cline { 4 - 4 } & & 1 & 2 \\
\hline BM (60\%) LK (40\%) & 30 & 2.267 & \\
BM (40\%) LK (60\%) & 30 & & 3.000 \\
BM (50\%) LK (50\%) & 30 & & 3.100 \\
Sig. & & 1.000 & .708 \\
\hline
\end{tabular}

Based on DMRT result, food bar with a proportion of $40 \%$ red rice flour and $60 \%$ yellow pumpkin flour and the proportion of $50 \%$ red rice flour and $50 \%$ yellow pumpkin flour make a more solid food bar compared to $60 \%$ rice flour and $40 \%$. The proportion of red rice flour and pumpkin flour really does affect the blendability of food bar. Yellow pumpkin flour has good flour quality because it has good gelatinization properties, so it can form a dough with good consistency, elasticity, and viscosity. The carbohydrate of yellow pumpkin flour is also quite high. This carbohydrate is very crucial in process of making starch dough. Starch granules will be attached to the protein during dough creation. The attachment between starch granules and protein will lead to continuity of the dough structure (Hendrasty, 2003).

The highest average acceptance is food bar with the proportion of $50 \%$ red rice flour and $50 \%$ yellow pumpkin flour which is 3.17. This average score is categorized as 'quite favorable'. The result of one-way ANOVA test (Table 8) shows that the proportion of red rice flour and yellow pumpkin flour does influence the food bar's favorite level.

Table 8. One-way ANOVA test on favorite level

\begin{tabular}{lcrccc}
\hline & Sum of Squares & df & Mean Square & $F$ & Sig. \\
\hline Between Groups & 6.489 & 2 & 3.244 & 3.421 & .037 \\
Within Groups & 82.500 & 87 & .948 & & \\
Total & 88.989 & 89 & & & \\
\hline
\end{tabular}

The result of one-way ANOVA test shows that the proportion of red rice flour and yellow pumpkin flour does influence the food bar's favorite level. Based on DMRT, panelists prefer food bar with the proportion of $50 \%$ red rice flour and $50 \%$ yellow pumpkin flour. Food bar with a proportion of $50 \%$ red rice flour and $50 \%$ yellow pumpkin flour has a light brown color, smells just like red rice and yellow pumpkin, tastes quite sweet and just red rice and yellow pumpkin, and also quite solid. 
Table 9. DMRT result on favorite level of the food bar

\begin{tabular}{lccc}
\hline \multicolumn{1}{c}{ Food Bar } & \multirow{3}{c}{ Subset for alpha $=0.05$} \\
\cline { 4 - 4 } BM (40\%) LK (60\%) & 30 & 2.567 & \\
BM (60\%) LK (40\%) & 30 & 2.633 & \\
BM (50\%) LK (50\%) & 30 & & 3.167 \\
Sig. & & .792 & 1.000 \\
\hline
\end{tabular}

Based on DMRT, panelists prefer food bar with the proportion of $50 \%$ red rice flour and $50 \%$ yellow pumpkin flour. Food bar with a proportion of $50 \%$ red rice flour and $50 \%$ yellow pumpkin flour has a light brown color, smells just like red rice and yellow pumpkin, tastes quite sweet and just red rice and yellow pumpkin, and also quite solid. The best results of food bars of red rice flour and yellow pumpkin flour are obtained based on organoleptic tests that have been done as well as one-way ANOVA test and DMRT (Table 10).

Table 10. Best Average Score of Organoleptic Properties of Food Bar with DMRT

\begin{tabular}{cc}
\hline Criteria & Proportion of red rice flour and yellow pumpkin flour \\
\hline Color & No effect \\
Smell & No effect \\
Taste & $50 \%: 50 \%=2,33$ \\
& $60 \%: 40 \%=2,43$ \\
Blendability & $40 \%: 60 \%=3$ \\
Favorite Level & $50 \%: 50 \%=3,1$ \\
\hline
\end{tabular}

The best result of the food bar from the DMRT is the food bar with a proportion of $50 \%$ red rice flour and $50 \%$ yellow pumpkin flour. Food bars with a 50:50 proportion produce a color that tends to be darker than other samples due to the warming of the Millard reaction that occurs during the food bar maturation process due to the high carbohydrate content of the red rice flour and the yellow lust. This is in line with Farida, et.al (2016) asserting that Millard reaction occurs because yellow pumpkin flour has high carbohydrate content that can make colored product tends to darken. From the result of the organoleptic test, variation of formula have no significant effect on panelist's favorite level to aroma. While variation formula gives a real effect on the level of panelist preferences to taste parameters.

The formula with the highest amount of pumpkin flour that is $60 \%$ has the highest favorite value that is 2.43 while $50 \%$ pumpkin flour has a favorite value of 2.33 . From the data, it can be seen that there is a growing trend of adding pumpkin flour tends to increase the value of the panelist's fondness. This is in line with Farida, et.al (2016) assertion that yellow pumpkin flour has specific properties with typical aromas, colors, and flavors favored by the panelists. Overall the formula that has the best acceptance level is the 50:50 formula because it gives a combination of sweet and tasty flavor. Based on the best resulting product, nutritional content of food bar made from red rice flour and yellow pumpkin flour (Table 11). Food bar with selected formula then analyzed its nutritional content at Research Laboratory Jl. Ketintang. Formula with $50 \%$ yellow pumpkin flour and $50 \%$ brown rice has a high enough energy of $144.2 \mathrm{kcal}$ and contains vitamins $A$ and $\mathrm{C}$. Yellow, yellow and brown rice pumps have a dye that signifies vitamin A (Kulkani et .al. 2017) and vitamin C (Sharma, et al., 2013).

Table 11. Nutrient Content of Food Bar made from Red Rice Flour and Yellow Pumpkin Flour per 100 grams

\begin{tabular}{clrr}
\hline No. & Nutrition & \multicolumn{2}{c}{ Total } \\
\hline 1. & Energy & 144,2 & $\mathrm{kcal}$ \\
2. & Carbohydrate & 26 & $\mathrm{gram}$ \\
3. & Calsium & 15,38 & $\mathrm{mg}$ \\
4. & Fat & 4,56 & $\mathrm{gram}$ \\
5. & Protein & 2,18 & $\mathrm{gram}$ \\
6. & Phosphor & 34,32 & $\mathrm{mg}$ \\
7. & Vitamin A & 83,04 & $\mathrm{RE}$ \\
8. & Vitamin B1 & 0,04 & $\mathrm{mg}$ \\
9. & Vitamin C & 13,26 & $\mathrm{mg}$ \\
\hline
\end{tabular}




\section{Conclusion}

The effects of the proportion of red rice flour and yellow pumpkin flour on the organoleptic properties of the food bar which include color, smell, taste, blendability, and favorite level are as follow: there is a significant influence of the proportion of red rice flour and yellow pumpkin flour on the organoleptic properties of taste, blendability, and favorite level of the food bar, and there is no significant effect of the proportion of red rice flour and yellow pumpkin flour on the organoleptic properties of color and smell of the food bar. The best resulting product is the food bar with proportion of $50 \%$ red rice flour and $50 \%$ yellow pumpkin flour. Criteria of the food bar include a light brown color and an average score of 3.27; smell like red rice and yellow pumpkin with an average score of 2.27; quite sweet and taste quite like red rice and yellow pumpkin with an average score of 2.33; quite solid with an average score of 3.1; the favorite level is 'quite favorable' with the average score of 3.17 .

\section{References}

Ekafitri, R.I. dan Faradilla, F. 2011. Pemanfaattan komoditas lokal sebagai bahan baku pangan darurat. Jurnal Pangan, 20(2),153-161.

Farida, S. N. et. al. 2016. Physical, chemical and sensory characteristics study of instant baby porridge based on lima beans tempeh flour (phaseolus lunatus), red rice flour (oryza nivara) and yellow pumpkin flour (cucurbita moschata). Jurnal Teknosains Pangan, 5(4), 32-39.

Goufo, P. and Trindade, H. 2014. Rice antioxidants: phenolic acids, flavonoids, anthocyanins, proanthocyanidins, tocopherols, tocotrienols, y-oryzanol, and phytic acid. Food Science \& Nutrition Journal, 2(2), 75-104.

Imanningsih, N. 2012. Gelatinisation profile of several flour formulations for estimating cooking behaviour. Penel Gizi Makanan, 35(1), 13-22.

Kulkani, A. S, et.al. 2017. Development of technology for the manufacture of pumpkin ice cream. Indian J Dairy Sci, 70(6), 701-706.

Kusumastuty, Fandianty, I. dan Julia. 2015. Formulation pf rice bran fluor and coen fluoe as emergency food product. Indonesian Journal of Human Nutrition, 2(2), 68-75.

Nuryani. 2013. The Potential of subtitution white rice with brown rice as a stampel food for preventing diabetic mellitus. Media Gizi Masyarakat Indonesia, 3(3), 157-168.

Pendong, L., Porajouwa, O., and Lyndon, R. J. 2017. Analisis usaha tani labu kuning di desa singsingon raya, kecamatan passi timur, kabupaten bolaang-mongondow. Jurnal AgriSosio Ekonomi Unsrat, 13(2), 87-98.

Sharma, S. et. al. 2013. Nutritional quality characteristics of pumpkin fruit as revealed by its biochemical analysis. International Food Research Journal, 20(5), 2309-2316.

Silfia. 2012. Pengaruh substitusi tepung pisang pada pembuatan brownies terhadap sifat kimia dan penerimaan organoleptik. Jurnal Litbang Industri, 2(2).

Suismono, and Hidayah, N. 2011. Pengembangan diversifikasi pangan pokok lokal. Jurnal Pangan, 20(3), 295-314. 